\title{
ECONOMIC AND LEGAL FACTORS INFLUENCING SOCIAL RELATIONS IN THE STATE
}

\author{
Inna Yefimova ${ }^{1}$, Olexander Karnaykhov ${ }^{2}$ \\ University of Customs and Finance, Ukraine
}

\author{
Volodymyr Reznichenko ${ }^{3}$ \\ Mariupol State Institute of Interregional Academy of Personnel Management, Ukraine
}

\begin{abstract}
This study identifies global factors conditioning the global problematic of the direction of social development. Global threats were evaluated and defined as dangerous processes, phenomena, and situations that cause harm to health, safety, well-being, and the lives of all humanity, and require to be eliminated. The essence of global risks was defined. These risks were identified as events or conditions that may cause a significant negative effect for several countries or spheres within a strategic period if they occur. Global problems were conceptualized. These problems were defined as phenomena, matters, and situations that are not completely understandable, interesting, actual, require solving and regulation, and in addition do not have unified solutions. Current global challenges were analysed, defined as strategic guidelines that cause transformational changes and are receiving attention from humanity. Global trends were defined as courses of social development. The composition and role of global actors were described and defined as international organizations, leading states, regional organizations, powerful corporations, institutional investors, large cities, and well-known personalities. Directions of positive courses of social development were developed by means of using the authors' mechanism of solving the global problematics.
\end{abstract}

Key words: globalization, social development, global factors, global problematics, global processes.

JEL Classification: A13, F01, F6

\section{Introduction}

The comprehension of factors determining the process of social development is a primordial aspiration of scientific thought. Unlike past trends, the current course of social development is stipulated by the process of globalization forming a unified social space with common global factors in it.

The goal of this research thus consists in the conceptualization of global factors influencing the course of social development. To achieve this goal, we defined and performed the following tasks: to evaluate global threats, to define the essence of global risks, to concept the essence of global problems, to analyse present global challenges, to exposed global trends, and to describe the composition and role of global players.

The global problematics of the course of social development from the twentieth to twenty-first centuries has been studied by many scholars (see: Amin,
1996; Dreher, 2006; Filipenko, 2007; Gelsdorf, 2010; Lukianenko et al., 2013; Madsen et al., 2016; Richard, 2003; Sardak, 2011, 2013; Sassen, 2006; Scudder, 2010 Stukalo, 2006; Went, 2004; Zghurovskyi et al., 2010; Hillebrand et al., 2010). In the twenty-first century, this matter remains topical. Scientific searches have been activated by means of attracting an increasing number of researchers to this scientific discussion. However, despite a great number of publications concerning separate matters in this sphere, the problematic of the direction of social development has not received a complex systematic analysis. It thus requires further research aimed at the conceptualization of global systemically important factors.

The main sources of the research include published works by scientists investigating urgent matters of social development, as well as data presented by international organizations.

\footnotetext{
Corresponding author:

${ }^{1}$ Department of Criminal Law Disciplines, Faculty of Law, University of Customs and Finance.

E-mail: inna vitaminka@i.ua

${ }^{2}$ Department of Criminal Law Disciplines, Faculty of Law, University of Customs and Finance.

E-mail: olexandr.karnauhov@gmail.com

${ }^{3}$ Mariupol State Institute of Interregional Academy of Personnel Management.

E-mail: rva260778@gmail.com
} 
The scientific solution to the problem concerning the direction of social development requires the creation of methodological tools adapted to the current terminological apparatus, research methodology, and statistical base.

The methodological basis of this study consists of using a systematic approach and methods: historical, logical, and theoretical generalization analogies abstraction observation; quantitative and qualitative comparison; complex and structural analysis; synthesis; grouping; thought experiment; and modelling.

The logic of the research consists in the analysis of theoretical statements and empirical data in the sphere of covering global processes and performing systemoriented synthesis of scientific and methodical basics of factor influence on the direction of social development.

\section{Global threats. Global risks. Global problems}

In the twenty-first century, the direction of social development is defined through the influence of global factors that are under permanent transformation. On the ground of studying scientific sources presented in the list of references, the authors have defined that the main global factors defining the direction of social development include global threats, global risks, global problems, global challenges, global trends, and global actors (see Figure 1).

Global Threats. When viewing these six identified factors, we should note the following: the phenomenon of social development consists of the fact that this development is preceded by certain threats, and these threats, in turn, cause definite risks. As a consequence of the deployment of globalization processes, global threats began to form. According to data presented by various global sources (UNO, the World Health Organization [WHO], World Economic Forum, Transparency International, Global Footprint Network, International Energy Agency, World Resources
Institute, and British Petroleum), the main threats to the sustainable development of humanity are the global decrease of energy security (ES), the imbalance between the biological abilities of the earth and the requirements of humanity in the biosphere in the context of changes in the demographic structure of the world (BB), a growing inequality between the people and countries of the world (GINI), the spread of global diseases (GD), child mortality (CM), corruption progression (CP), limited access to drinking water (WA), global warming (GW), state flexibility (SF), and global climate changes and natural disasters (ND) (Zghurovskyi et al., 2010). American scientist T. Scudder views global threats through the prism of providing standards of living: poverty and a growing gap between poor and rich people; cultural, economic, political, and religious fundamentalism; and global degradation of the environment. According to this author, these threats arise because of the process of consumption, the growing population, and urbanization (Scudder, 2010).

Global Risks. Global risks are viewed as a separate category, but this category is almost completely equated with global threats (World Economic Forum, 2016). An appropriate interpretation of the World Economic Forum consists of the fact that a global risk is an uncertain event or condition that in the case of its occurrence may cause a significant negative effect for several countries or spheres over the next ten years (World Economic Forum, 2016, 11). During the last three years, the five biggest global risks have been: climate changes (global warming), weapons of mass destruction, water disasters, large-scale uncontrolled migrations, and price shocks related with the price to energy sources (price increase or decrease) (World Economic Forum, 2016, 11). Geopolitical aspects take an important position among global risks. For a period of more than a single year, global risks are a significant factor in social development. This can be explained by the influence of global risks on economic dynamics, including financial crises. A high level of structural

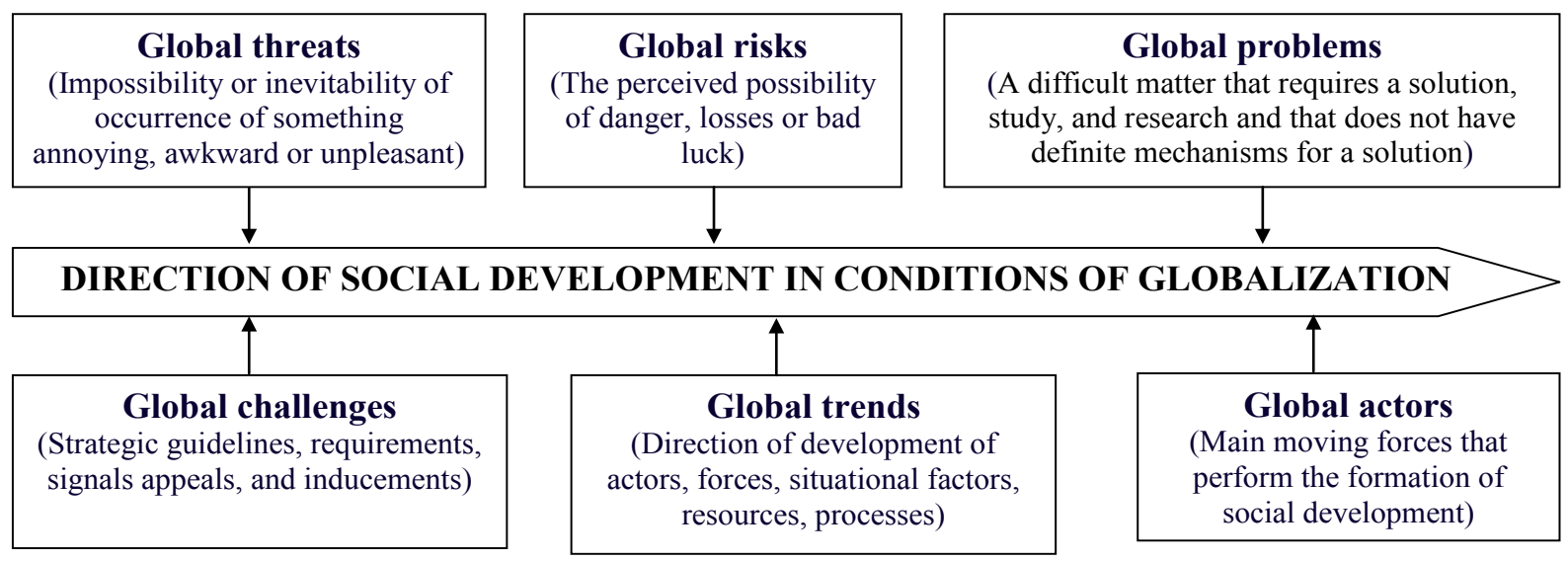

Figure 1. Global factors influencing the direction of social development 
unemployment and underemployment result in and are accompanied by deep social instability (Tymoshenko et al., 2015). Global risks exert a potential influence on society and require prospective protection of the social and economic sphere.

Global Problems. Global risks and threats cause global problems in social development. Given its very essence, a problem is not a negative element; it simply appears as a phenomenon in the process of development. This phenomenon causes contradictions, misunderstandings, the results of previous mistakes, and irrational or shortsighted decisions. The existing global problems of social development include the following: limited knowledge about the universe; origins of civilization; the mission and role of humans; absence of effective mechanisms for the progressive development of humanity; impossibility of preventing imbalances in demographic, economic, social, and managerial processes that lead to conflicts and wars; negative technical impact on the environment of vital human activities; shortage of resources; and the necessity of mastering and implementing new technologies (Mayer, 2003; Heiets et al., 2005).

One billion people do not have access to clean drinking water; 1.6 billion people live without electricity; three billion people live without adequate sanitation. One billion people are illiterate. Twenty percent of the world's population have insufficient food, and currently, almost every fourth child has an insufficient body weight because of lack of food, as well as lack of water, poor sanitary conditions and medical services, incorrect nutrition, and insufficient care. The gap between the richest and the poorest countries was defined through correlation as $72: 1$. In 2005, 1.4 billion people lived in conditions of extreme poverty with a daily income of less than 1.25 USD per day, and in 2015 the number of such people was $920-970$ million. The three richest people in the world have capital exceeding the incomes of forty-seven poor countries; of the world; the 475 richest people control the capital of half of all humanity. The correlation between one-fifth of the richest part and one-fifth of the poorest part of the world population has reached 1:75. During the last twenty years, the gap between the richest and the poorest group of people in the world has increased almost tenfold (Zghurovskyi et al., 2010; Lukianenko et al., 2013; World Bank, 2015).

There is no doubt that the world community is going through a difficult period. Technological development, economic prosperity, and cultural evolution are global aspects of the development of a society that have increased our ability to solve many social hardships still present in our life. The gaps between poverty and prosperity within and between these countries are still growing; according to European specialist J.F. Richard, if we do not act decisively before 2020 the number of people living on less than 2 USD per day may significantly increase and actually exceed three billion people (Richard, 2003). Protection of the natural environment is one global problem. A number of other serious problems, such as global pandemic diseases, illegal drug trafficking and smuggling of people, are creating new hardships for governments throughout the world.

In general, problems caused by past phenomena or events are taking place in the present and may affect all spheres of human activities, any territory, and time of the functioning of human resources. We propose classifying social problems according to the following criteria.

$\checkmark$ the nature of their origin: those conditioned genetically, those formed by the environment, artificial; $\checkmark$ the environment of their occurrence: natural, biological, technical, economic, social, managerial;

$\checkmark$ reality: real objective and subjective problems, virtual problems, pseudoproblems;

$\checkmark$ expectation: expected and unexpected problems;

$\checkmark$ threats: safe, dangerous, and catastrophic problems;

$\checkmark$ the possibility of overcoming: problems that can be solved and those that cannot be solved;

$\checkmark$ period of existence or influence: temporary, current, short-term, medium-term, long-term, strategic, and constant problems;

$\checkmark$ the rate of their occurrence or deployment: slow, rapid, and sudden problems;

$\checkmark$ the term of their occurrence: primordial, past, present-day, and future problems;

$\checkmark$ usefulness: useful, neutral, and harmful problems;

$\checkmark$ consequences or results: positive problems, problems without consequences or without results;

$\checkmark$ sphere of activity: food problems, problems concerning raw materials, energy (power) problems.

\section{Global challenges. Global trends}

The global problematic of social development gives birth to global challenges. Challenges are strategic guidelines that are desired by humanity compelled on one hand and voluntarily on the other. These are demands, signals, claims, and encouragement concerning the performance of certain actions in the sphere of production, distribution, exchange, and consumption on a global scale that cause certain transformational changes. Challenges arise mainly because of two reasons. The first consists of unsolved current problems and threats in the society that affect the quality of human activities. The second consists of people's aspiration to improve their mode of life, allow their families to prosper, and ensure a decent future for their descendants. People thus define their strategic guidelines; on one hand, they do this compelled and on the other hand, they do this voluntarily.

Specialists in the World Economic Forum have defined ten global challenges that require the cooperation of humanity (World Economic Forum 2015):

- Food security and development of agriculture. The forecasts claim that by 2050 the population of our planet 
will be nine billion people. In order to feed this number, 60 percent more food will have to be produced, which in turn requires the prosperity of small farmers.

- Economic growth and social integration. This problem consists of the fact that the recovery of the global economy after the crisis has been very weak and nonuniform.

- Employment, habits, and human capital are the three driving forces forming future university education. These elements will form the essence of higher education.

- Safety of the environment and resources. This presupposes that the problem of changing climate will be solved.

- The future of the global financial system. This sphere requires the creation of world institutes because the monetary and credit system is unstable and is subject to various crises.

- The future of the Internet. Given the problem of websites and e-mail accounts being hacked, the Internet has forever altered the safety of information at all institutions.

- Gender parity, concerning the provision of gender equality, and women's rights and opportunities in developing countries.

- Global criminality and fighting corruption, which is one of the ways of solving the problem of global poverty.

- Long-term investments, infrastructure, and development, including the introduction of innovations to infrastructure and industry, and carrying out various experiments in this sphere.

- International trade and investments. The main global challenges in this sphere depend on China; the issue is how the economy of this country will be developed in world markets.

Kristen Gelsdorf defines global challenges as any trends with the potential for serious global influences; thus certain humanitarian problems arise and these problems must be solved by world humanitarian organizations (Gelsdorf, 2010). Gelsdorf also presents a list of global challenges: climate changes. Increasing temperature will collaterally lead to the extinction of territories; poverty and social inequality. Approximately one-half of the world's population lives at less than 1 percent of the world's wealth; financial and economic crises. The decreased rate of world economic development has led to an increase in poverty and unemployment, which in turn causes an increased demand in developing countries for humanitarian help; food crisis. Over one billion people all over the world suffer from hunger; 25,000 children die every day of insufficient nutrition; currently, two billion people suffer from microdeficit of nutrients. Production of food will not be able to grow by 50 percent by 2025 compared to the present-day level in order to keep up with the growing population, so the food crisis will threaten human life worldwide; a deficit of water. The number of people without access to safe water will increase from over one billion people to two billion people by 2025; energy security. The demand for energy is growing, which will lead to a deficit of energy resources by 2030 and will create stronger stimuli to make investments in renewable energy sources; migration, which is growing and creates challenges within countries, as well as on the global level; increase of population and demographic shift. By 2025, the world's population is predicted to increase to eight billion people, which will lead to an increased load on global resources and global institutions; Urbanization. By 2060 , the population in cities will increase twofold in Asia, and in Africa will increase by 150 percent. This will lead to significant social inequalities and risks, including significant problems with health, insufficient nutrition, underemployment, and low income. These problems are a constant threat to the safety of billions of people; Pandemic diseases and infectious diseases. According to forecasts, any large-scale pandemic influenza could result in two to sixty million deaths.

Global Trends. The abovementioned global threats, risks, problems, and challenges of social development affect the formation and development of global trends. A global trend as a direction of social development is a continuous process; the main modern global trends are: internationalization, socialization, integration, disintegration, urbanization, regionalization, homogenization, transnationalization, vertically oriented corporatization, shadowing, differentiation, polarization, confrontation, marginalization, fragmentation of state activities, sharpening of competition, activation of innovative and investing activities, stratification of the society, deepened international division of labour in the spheres of specialization and cooperation of production, and concentration of management (World Economic Forum, 2016).

According to an investigation by S.E. Sardak and V.T. Sukhoteplyi, the most significant critical events will start to occur in 2030 when the world enters a new period of global dynamics in the sphere of human-resources development (Sardak et al., 2013). Social development will take place in accordance with identified scenario forecasts, depending on the dominating direction of human creative activities and on the size of the world's population (Sardak, 2011).

According to the National Intelligence Council, the improvement of rights and opportunities of individuals and distribution of power between states and from states to informal networks will cause a significant influence. This process will be facilitated through the increase of Asia's share in the world economy, as well as through democratization on the international and national levels. Two main megatrends can be defined (National Intelligence Council 2012, iii): the demographic megatrend, an especially quick ageing; and the resource megatrend, the growing demand 
for resources that, in the case of food and water, may lead to a deficit of resources. These trends will gain a significant momentum during the following fifteen to twenty years. In general, four megatrends are described in the report: 1) Individual improvement of rights and opportunities, which will present an opportunity to lower the level of poverty, increase the global middle class, improve the level of education, and use new communications, technologies, and advantages of the health care system. 2) Diffusion of power - no hegemonic power will be present. It will be the multipolar world. 3) The demographic megatrend. 4) The resource megatrend.

Global socialization also appears to be a recent global trend (Sardak et al., 2017). The globalization and integration processes taking place within a national economy penetrate all spheres of life, not only the economy but also the social sector (Simakhova, 2016). The main goal of increasing the social orientation of world countries consists of the restriction and neutralization of the potentially destructive nature (in the social context) of the market (Bilska, 2015). International relations in the "new Europe" are thus formed in the process of global socialization. By means of this socialization, the EU introduces its constituent liberal standards to Central and Eastern Europe. Socialization in Europe can be best explained as a process of rational actions in the normative sphere of the legalized international situation (Shimmelfennig, 2000). F. Shimmelfennig views global socialization only from the aspect of the political and democratic spheres. We give socialization a broader meaning, defining it as a trend and as a process in the economic sphere, as well as in the social sphere. Financial globalization also contributes to the reinforcement of the abovementioned trends (Stukalo, 2006).

At the end of the first decade of the twenty-first century, global actors also caused an increasing impact on the direction of social development in the conditions of globalization. The issue of global actors is a matter sufficiently urgent to be discussed by scientists. There is a proposal to define global actors as global institutions (organizations), such as the WTO or UNO, communities of experts, TNC, or separate natural persons and legal entities with the significant power to influence world policy (Madsen et al., 2016). First globalization contributed to the development of new forms of governmental authorities (Von Bogdandy et al., 2012). In other words, the traditional view of public authorities related to the state and politics cannot be simply transferred to the global sphere. Regarding global actors, this means that they have social and political influence in the sense of exercising public power outside their countries. The second point is that scientists have proved that nongovernmental global actors play a significant role in the sphere of global policy and the construction of global society (Sassen, 2006). World religious confessions also play an important role; for example, the state enclave Vatican, which is an example of the civil power of the Holy See of the Catholic Church), has its own non-commercial planned economy. The budget of the Vatican is 310 million USD, and the general capital of this country is about 1 trillion USD. The sources of income include donations from Catholics all over the world. In addition, great profit is brought by tourism - selling postage stamps, Vatican coins, Euros, souvenirs, payments for visiting museums. The greater part of the labour force is comprised of Italian citizens. The words of Holy Fathers have significant importance in directing global trends of the world economy by means of over one billion believers representing the electorate. So, they define the direction of human resources management by generating ideas and their implementation in form of strategic guidelines, values, and priorities (Vatican, 2013).

We define global actors as follows: international organizations; leading states; regional economic and financial organizations; powerful corporations; institutional investors (pension funds, investment funds, insurance companies); large cities; well-known personalities (the richest owners, hierarchs of religious confessions, members of royal families, top managers of large companies, influential politicians, leading scientists, criminal authorities, heads of orders and societies as well as well-known sportsmen, actors, artists and other personalities) (Filipenko, 2007; Yakubovskiy, 2002).

The role of global players in the process of directing global development is proved through statistical data. Transnational corporations (TNCs) control over 50 percent of the world's industrial production; 67 percent of international trade; over 80 patents and licenses for new technical facilities, technologies, and knowledge; and almost 90 percent of direct foreign investments. Movements of only 1-2 percent of their total cash can significantly change the parity of national currencies. The economic opportunities of large TNCs can be compared with the GDP of average countries. The market capitalization of separate TNCs exceeds 500 billion USD, and annual volumes of sales are 150-200 billion USD (Samofalov, 2009). Less than 1 percent of corporations form the core of the global economic hyperstructure that controls half of the world economy. At the end of the first decade of the twenty-first century, there were approximately $82,000 \mathrm{TNCs}$, with 810,000 foreign branches. Thanks to 90 percent direct foreign investments, they had a significant influence on national economies (Shabalina, 2012). Moreover, in 2012 the general cost of TNC assets increased to 87 trillion USD, which is fifteen trillion more than the world's GDP. The level of employment in TNCs was 72 million people, which is 2.2 percent of working people in the world (Kuznecov, 2013). 


\section{Positive directions of social development}

In the twenty-first century, there is an increased necessity to search for ways to level the influence of dangerous factors on society because the traditionally recognized issues of the global problematic are supplemented by new global processes formed by past and modern generations (Zghurovskyi et al., 2010).

Correcting the direction of social development in conditions of globalization under positivistic ideas will require: accepting global standards used for managing the development of human resources; designing a new world economic system; reforming the system of global institutionalization, intellectualization, and informatisation of the social environment; optimization of migratory movements of human resources; improvement of systems of supragovernment management and state management; optimization of the mechanism of international management and marketing; transformation of forms and methods of trading and economic exchange and collaboration; and deepening the level of economy socialization and labour humanization.

After analysing theoretical basics of forming a global problematics in society, we can assume that this context is formed due to the predominant influence of human factors - various interests, various points of view, unwillingness to make concessions, and so on - and measures concerning the process of optimization often meet resistance because of their compulsory nature. This requires the construction of a mechanism for solving these problems, a mechanism that should be based on the management of human resources development. In Figure 2, we propose a simplified scheme of the mechanism for solving the global problematics.

As can be seen in Figure 2, the process of solving the global problems requires the organization of monitoring that would provide diagnostics according to certain signals, and that would ascertain the history, dynamics of formation, and development of a certain problem situation. This work should be performed by an organization with authority in accordance with the importance of the given problem. Received information will provide an opportunity to describe the problem and formalize it, for example, by building a model, to define the scale of the problem, the composition of human resources, and the form of their participation. On the basis of performed diagnostics, one can develop a plan to solve the problem by defining programs of actions,

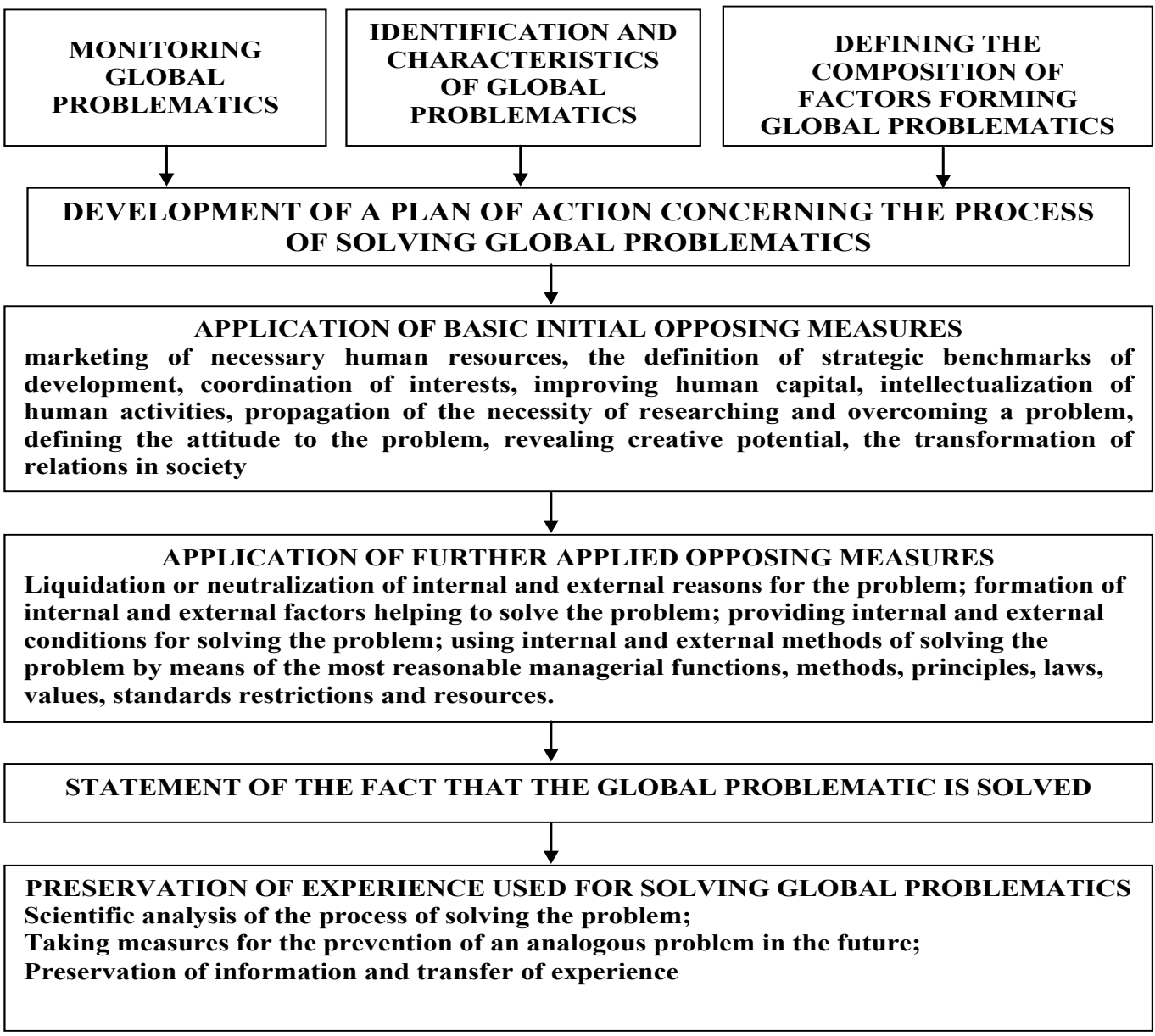

Figure 2. Simplified scheme of the mechanism for solving the global problematics 
prognoses (forecasts), responsible personalities, the scope of authorities, necessary resources, time, and so on. After planning, it is necessary to organize initial events. This presupposes work in the spheres of information, communication and education, and coordination with human resources engaged in the internal and external environment. Further events apply practical forms of solving the problem.

\section{Conclusion}

In conclusion, we should note that the beginning of the twenty-first century has its own problems of social development that is a consequence of new conditions of human activity and the changing nature of social relations. This problematic is caused by the formation of a unified common global space in the sphere of policy, economy, science, culture, and production - that is, it is caused by globalization. Modern threats, risks, problems, challenges, and trends, which some decades ago were local and various in various regions, have now become global. The methods of managerial influencing of human resources appear to be completely dependent on the above-mentioned global components activated by global actors.

The presence of the abovementioned problem issues in the social and economic systems of different management levels indicates systematic mistakes. They are historically formed and need to be adequately addressed to modern realities. This calls for the definition of a global ideological imagination of mankind for the organization of its life and development in the future. However, the formalization and certainty of the outlook of human civilization will require the implementation of transformations in the field of morality and social responsibility, which now dominate multifaceted views within the limits of polar contradictions from selfishness to altruism, from plunder to charity, from freedom to full dependence, from recognition of people equal rights to the recognition of choice, from compulsory liability to the possibility of its avoidance, from restrictions to total permissiveness, from unlimited domination to complete obedience, etc. And it must be borne in mind that these changes can provoke the emergence and aggravation of new global conflicts.

In general, it must be conceded that the further direction of social development will depend on the forms and pace of globalization. As a result of the telecommunication revolution, the world is turning into a "global village", where instability and rupture prevail, which makes it necessary to find a new balance of interests based on open and fruitful dialogue. Accordingly, in order to optimize the socio-economic life of humanity, it is necessary not to stop globalization, but to improve its quality by creating opportunities for countries to find their own ways to overcome problems and achieve sustainable prosperity and security, which will determine the positive direction of social development.

In the context of globalization, in order to prevent the loss of positive hereditary economic achievements and prevailing socio-cultural civilizational values, improve the environment of human life, and protect the rights, interests, and freedoms of the world, there is a need to optimize global factors, which influence the directions of social development. Further research should analyse the development of scientific and methodical basics and applied mechanisms of directing social development in accordance with positivistic and progressive ideas.

\section{References:}

Amin S. (1996). The challenge of globalization. Review of International Political Economy, 3, 216-259, DOI: $10.1080 / 09692299608434355$.

Bilska O.V. (2015). Social function of the state and implementation of this function in conditions of globalization challenges. Strategies of economic development of countries in conditions of globalization: Materials of the international scientific and practical conference, 1, 31-33.

Dreher A. (2006). Does globalization affect growth? Evidence from a new index of globalization. Applied Economics, 38, 1091-1110. DOI: 10.1080/00036840500392078.

Filipenko A.S. (2007). Global forms of economic development: history and contemporaneity. Kyiv: Znannya. Gelsdorf K. (2010). Global Challenges and their Impact on International Humanitarian Action. OCHA, PDSB. Heiets V.M. et al. (2005). Social and economic problems of information society. Sumy: universytetska knyga. Hillebrand E.E., Lewer J.J. and Zagardo J.T. (2010). Backtracking from Globalization. Global Economy Journal, 10, 1-14. DOI: 10.2202/1524-5861.1609.

Kuznecov A. (2013). The country is in the arms of transnational capital. Foreign Affairs chronicles, 1, 146-52.

Lukianenko D. et al. (2013). Globalnoe jekonomicheskoe razvitie: tendencii, asimmetrii, regulirovanie. Kyiv: KNEU.

Madsen M.R. and M.J. Christensen. (2016). Global Actors: Networks, Elites, Institutions. iCourts Working Paper, Series No. 44: https://ssrn.com/abstract=2731098 or http://dx.doi.org/10.2139/ssrn.2731098

Mayer D. et al. (2003). Main Problems of Economic Development. Kyiv: Lybyd.

National Intelligence Council. 2012. Global trends 2030: Alternative World, NIC.

Richard J.F. (2003). Urgent Global Problems, New Global Solutions Progressive Politics, 2.2, 80-84. 
Samofalov V. (2009). Global challenge multinational corporations. Dzerkalo tyzhnia, 37, 41-45.

Sardak S. (2011). Prospects for socioeconomic development of human resources under conditions of globalization. Actual Problems of Economics, 123, 217-225.

Sardak S. and Sukhoteplyi V. (2013). Periodization and forecast of global dynamics of human resources development. Economic Annals XXI, no. 3-4, 3-6.

Sardak S., Bilskaya O. and Simakhova A. (2017). Potential of economy socialisation in the context of globalisation. Economic Annals-XXI, 164(3-4), 4-8. DOI: https://doi.org/10.21003/ea.V164-01.

Sassen S. (2006). Territory, authority, rights: From medieval to global assemblages. Princeton, NJ: Princeton University Press.

Scudder T. (2010). Global threats, global futures: Living with declining living standards. Cheltenham: Edward Elgar. Shabalina L. (2012). Analysis of the impact multinational corporations on the economy of Ukraine. Ekonomika, 3, 59-64. Shimmelfennig F. (2000). International Socialization in the New Europe. European Journal of International Relations, 6, 109-39, DOI: $10.1177 / 1354066100006001005$.

Simakhova A.O. (2016). Analysis of the foreign economic factors impact on the welfare of Ukrainians in the conditions of the world integration processes. Marketing and Management of Innovations, 3, 263-71. Retrieved from: http://essuir.sumdu.edu.ua/handle/123456789/46483

Stukalo N. (2006). Evaluating The State of Financial Globalization: Ukraine's Specific Features. International Economic Policy, 1, 84-102.

Tymoshenko L. and Simakhova A. (2015). Sotsialno-ekonomichnyy rozvytok i yoho kerovane zabezpechennya $\mathrm{v}$ umovakh innovatsiynoyi modeli suspilnoyi dynamiky. Mekhanizm Rehuluvannya Economiky, 67, 58-78.

Vatican (2013). Apostolic exhortation Evangelii Gaudium of the Holy Father Francis. Retrieved from: http://www.vatican.va/holy_father/francesco/apost_exhortations/documents/papa-francesco_ esortazione-ap_20131124_evangelii-gaudium_en.pdf

Von Bogdandy A. and Venzke I. (2012). In whose name? An investigation of International Courts' public authority and its democratic justification. European Journal of International Law, 23, 7-41.

Went R. (2004). Economic globalization plus cosmopolitanism? Review of International Political Economy, 11, 337-55, DOI: $10.1080 / 09692290420001672822$.

World Bank (2015). World Development Report 2010. Retrieved from: http://www.worldbank.org/wdr (accessed 10 July 2015)

World Economic Forum (2015). 10 global challenges. Retrieved from: https://www.weforum.org/ agenda/2015/01/10-global-challenges-10-expert-views-from-davos/

World Economic Forum (2016). What are the biggest threats in 2016. Retrieved from: https://www.weforum.org/ agenda/2016/01/what-are-the-biggest-threats-in-2016

World Economic Forum (2016). The Global Risks Report 2016, $11^{\text {th }}$ edition. Geneva: World Economic Forum.

Yakubovskiy S.O. (2002). Investment activities of transnational corporations and their influence on competitiveness of national economies, Odessa: ORIDU UADU.

Zghurovskyi M.Z. et al. (2010). Analysis of sustainable development - global and regional contexts, Kyiv: NTUU KPI. 